\title{
Gastrointestinal manifestations of Talaromyces marneffei infection in an HIV- infected patient rapidly verified by metagenomic next-generation sequencing: a case report
}

\author{
Ying Zhou', Yongfeng Liu' ${ }^{2}$ and Ying Wen ${ }^{1 *}$ (I)
}

\begin{abstract}
Background: The manifestation of Talaromyces marneffei infection in some HIV-infected patients may be atypical. Cases with gastrointestinal involvement have rarely been reported. It is hard to make a diagnosis when patients are lacking the characteristic rash and positive blood culture.

Case presentation: Here, we described a patient living with HIV who complained of fever and abdominal pain, and was rapidly diagnosed with Talaromyces marneffei infection by metagenomic next-generation sequencing (mNGS) using formalin-fixation and paraffin-embedded (FFPE) samples of omentum majus tissue. We also reviewed reported related cases.

Conclusions: Talaromyces marneffei is an unusual cause of clinical presentations involving obvious abdominal pain and lower gastrointestinal bleeding, but can be included in the differential diagnosis. As an important diagnostic tool, the significance of mNGS using FFPE samples of lesions provides a more targeted diagnosis.
\end{abstract}

Keywords: Human immunodeficiency virus, Talaromyces marneffei, Gastrointestinal involvement, Metagenomic next-generation sequencing

\section{Background}

The common manifestations of Talaromyces marneffei infection in human immunodeficiency virus (HIV)-infected individuals consist of fever, anemia, weight loss, characteristic skin papules, respiratory signs, lymphadenosis, hepatosplenomegaly, and other organ involvement. In China, Talaromyces marneffei is mainly found in southern China. Therefore, HIV-infected patients with a travel history to southern China should have

\footnotetext{
*Correspondence: wenying666466@163.com

'Department of Infectious Diseases, The First Affiliated Hospital of China Medical University, No. 155, Nanjing North Street, Heping District, Shenyang 110001, Liaoning Province, China

Full list of author information is available at the end of the article
}

Talaromyces marneffei infection considered when they first present with gastrointestinal manifestations.

\section{Case presentation}

A 33-year-old Chinese man presented with continuous fever for one month from July 15th, 2019, followed by 20 days of abdominal pain. The initial highest temperature was $38.9^{\circ} \mathrm{C}$, accompanied by night sweats, anorexia, fatigue, weight loss and diarrhea (watery stool, 4-5 times per day). On July 25th, 2019, the patient presented with intolerable abdominal pain and body temperature had increased to $40^{\circ} \mathrm{C}$. HIV infection was confirmed and the patient's $\mathrm{CD} 4^{+} \mathrm{T}$-cell count was

(c) The Author(s). 2021 Open Access This article is licensed under a Creative Commons Attribution 4.0 International License, which permits use, sharing, adaptation, distribution and reproduction in any medium or format, as long as you give appropriate credit to the original author(s) and the source, provide a link to the Creative Commons licence, and indicate if changes were made. The images or other third party material in this article are included in the article's Creative Commons licence, unless indicated otherwise in a credit line to the material. If material is not included in the article's Creative Commons licence and your intended use is not permitted by statutory regulation or exceeds the permitted use, you will need to obtain permission directly from the copyright holder. To view a copy of this licence, visit http://creativecommons.org/licenses/by/4.0/ The Creative Commons Public Domain Dedication waiver (http://creativecommons.org/publicdomain/zero/1.0/) applies to the data made available in this article, unless otherwise stated in a credit line to the data. 
7 cells $/ \mu \mathrm{L}$. The patient was born in Shenyang, located in the north of China. However, since July 2018, he had worked and travelled a lot in Guangdong province, located in the south of China. The patient had eaten roasted bamboo rat in December 2018.

The patient experienced abdominal tenderness and rebound pain. Brain contrast magnetic resonance imaging (MRI) and chest computed tomography (CT) scans were relatively normal. Abdominal CT scans showed severe fatty liver, thickened and swollen small intestinal wall, pelvic cavity effusion, and thickened mesentery accompanied by multiple enlarged intra-abdominal lymph nodes (Fig. 1a, b). The patient had normal leucocyte and platelet counts and mild anemia. The patient displayed elevated C-reactive protein $(135.30 \mathrm{mg} / \mathrm{L})$ and galactomannan levels $(4.39 \mu \mathrm{g} / \mathrm{L})$. Serum ferritin was above $2000.00 \mu \mathrm{g} / \mathrm{L}$. Serum cryptococcal antigen was negative. Anti-neutrophil cytoplasmic antibodies were negative. Toxoplasma gondii IgM and IgG antibodies were negative. Cytomegalovirus (CMV) IgG antibody and herpes simplex virus IgG antibody were positive, while IgM antibodies were negative. Epstein-Barr virus (EBV) IgM antibody was negative while viral capsid antigen IgG and nuclear antigen IgG antibodies were positive. Serum CMV-DNA was undetectable. Whole blood EBV-DNA was undetectable. The HIV RNA load was $5.1 \times 10^{5}$ copies $/ \mathrm{mL}$. Blood bacteria and fungi cultures were repeated three times and all tests were negative. Fecal bacteria and fungi cultures were repeated three times and all tests were negative. We did not observe parasite eggs in the stool specimens. Giemsa stain of bone marrow aspirate did not find any pathogens. A bone marrow sample culture was not carried out due to insufficient bone marrow samples obtained.

For this kind of patient with obvious peritonitis despite a negative T-SPOT result, empirical anti-tuberculosis treatment with a regimen of isoniazid, rifampin, ethambutol, and pyrazinamide was prescribed at the day 4 of admission. A week later, fever and abdominal pain had worsened. The patient complained of diffuse abdominal pain and sustained fever. The patient displayed abdominal rigidity. At the day 12 of admission, fungal infection was suspected and omentum majus biopsy was performed. Hematoxylin and eosin (H\&E) staining showed granuloma with central necrosis and a large number of foamy macrophages, lymphocytes, and neutrophil infiltration. Periodic acid-Schiff (PAS) and Gomori's methenamine silver nitrate (GMS) staining showed clustered yeast in macrophages (Fig. 2). Acid-fast bacilli staining (using Ziehl Neelsen), CMV-antigen, TB-DNA, and EBV-DNA in paraffin-embedded tissue sections were all negative. The patient began antifungal treatment with amphotericin B. In order to identify the specific fungal species, particularly to differentiate between Talaromyces marneffei, histoplasma, and other deep fungal infections, FFPE samples were sent to BGI PathoGenesis
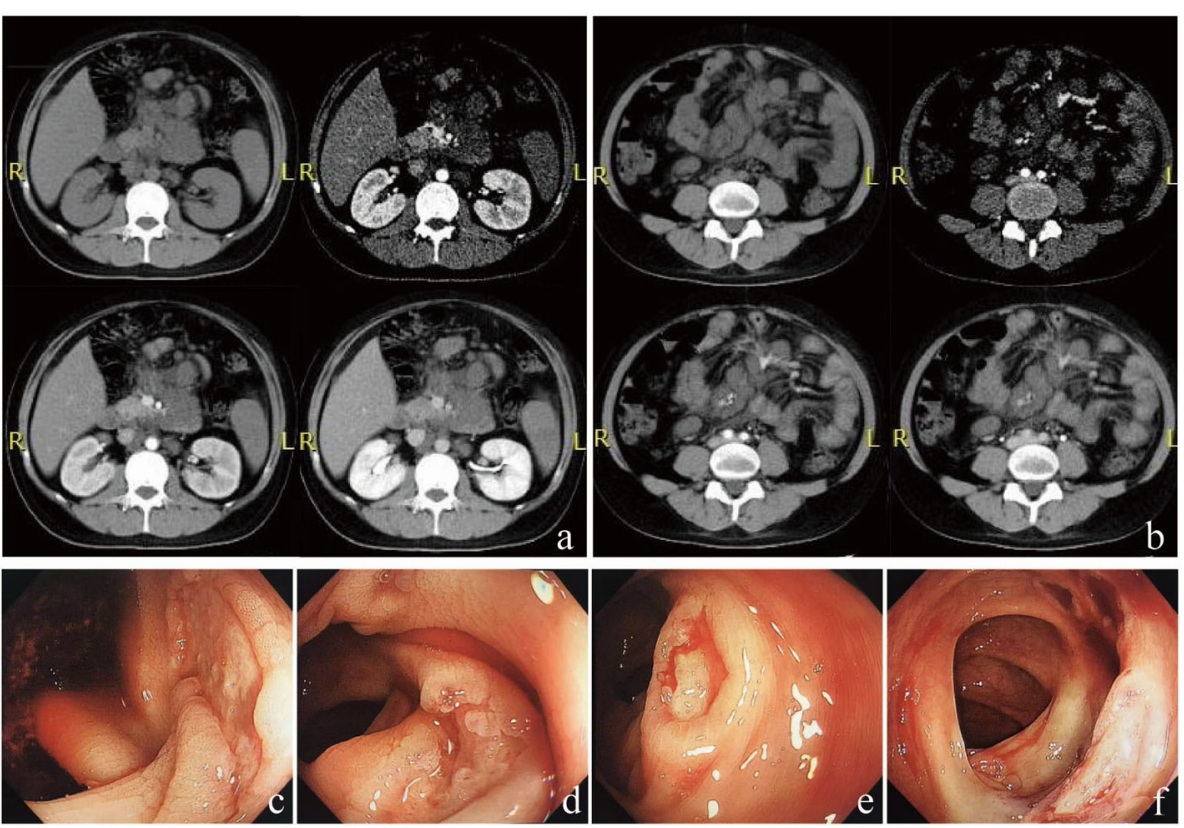

Fig. 1 Presentation of abdominal CT scan and colonoscopy. Abdominal CT scan showed severe fatty liver, pelvic cavity effusion (a), thickened and swollen small intestinal wall and thickened mesentery, accompanied by multiple enlarged intra-abdominal lymph nodes (a, b). Gastrointestinal endoscopy found multiple small shallow ulcers scattered in the cecum (c), ascending colon (d), transverse colon (e), and descending colon (f), partly accompanied by white exudates and active bleeding 


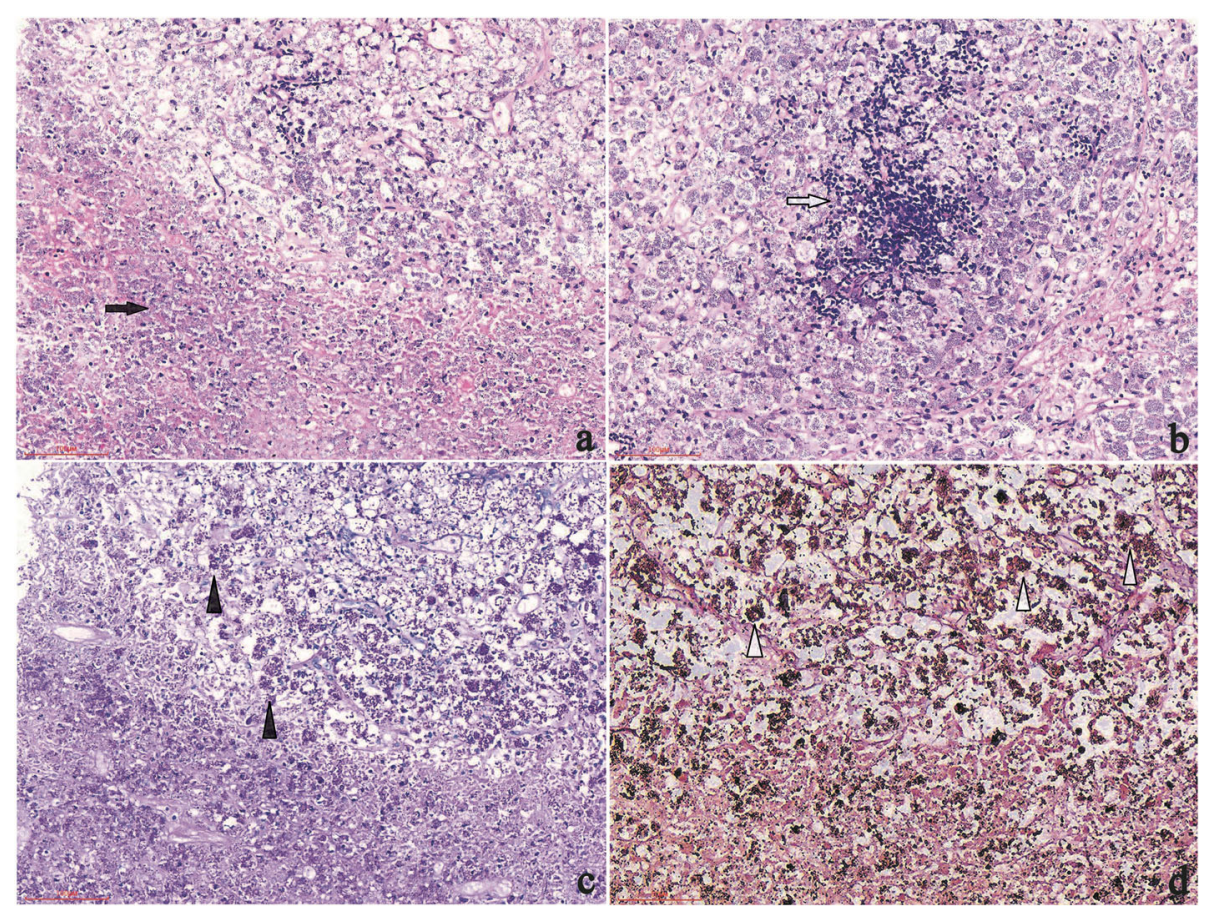

Fig. 2 Histopathology of biopsy samples. H\&E staining showing granuloma with central necrosis and concentrated inflammatory cell infiltrations involving foamy macrophages (containing a large number of yeasts), neutrophils (a) (200 x magnification), and lymphocytes (b) (200x magnification); Yeasts with positive PAS staining (c) (200 × magnification) and GMS staining (d) $(400 \times$ magnification) in macrophages

Pharmaceutical Technology (BGI-Shenzhen) for metagenomic next-generation sequencing (mNGS), which indicated Talaromyces marneffei infection 3 days later (Fig. 3). In brief, the experimental procedure was performed as follows: DNA from the patient's FFPE samples was extracted using the MagPure FFPE DNA LQ Kit following the manufacturer's instructions. The DNA library was constructed and sequenced, human sequences were excluded, and low-complexity reads were removed, the remaining data were classified by simultaneously aligning to four microbial genome databases, consisting of 4061 whole genome sequences of viral taxa, 2473 bacterial genomes or scaffolds, 199 fungi connected to human infection, and 135 parasites associated with human diseases [1].

Fever and abdominal pain rapidly resolved after the initial days of starting amphotericin B treatment, while gastrointestinal bleeding occurred with a total bloody stool volume of $1000 \mathrm{~mL}$. Gastrointestinal endoscopy revealed multiple small shallow ulcers scattered in the cecum, ascending colon, transverse colon, and descending colon, partly accompanied by white exudates and active bleeding (Fig. 1c-f). After endoscopic hemostasis therapy with 1:1 epinephrine solution injected around the lesion, the bleeding temporarily stopped. Amphotericin B treatment was continued followed by oral itraconazole. Intestinal bleeding had another two relapses and achieved spontaneous remission. The patient's serum creatinine increased to $120 \mu \mathrm{mol} / \mathrm{L}$ during amphotericin B treatment, but tenofovir alafenamide fumarate was not available in China at that time, therefore, we suggested to use abacavir, and spent weeks to detect HLA-B5701 and applied for abacavir. After eight weeks of anti-fungal treatment, ART was initiated with a regimen of lamivudine, abacavir, and dolutegravir. After 12 weeks of antifungal treatment, abdominal CT indicated that the thickened mesentery and small intestine had recovered, the retroperitoneal lymph node had shrunk, and colonoscopy showed that the colon lesions had recovered. A 12month follow-up revealed that the patient's CD4+ T-cell count had increased to 85 cells $/ \mu \mathrm{L}$ and HIV RNA was undetectable. The patient continues to take $200 \mathrm{mg}$ itraconazole per day as secondary prevention until CD4 + T cells count reach 100 cells $/ \mu \mathrm{L}$ for at least 6 months.

\section{Discussion and conclusions}

This is a case of gastrointestinal Talaromyces marneffei infection with negative blood culture, and the absence of any respiratory involvement or rash. The mNGS rapidly aided in identifying Talaromyces marneffei nucleotide sequences in omentum majus FFPE samples from our patient, which had never been previously reported; In 3 previous published papers, mNGS has been reported to help to diagnose Talaromyces marneffei infection in the 


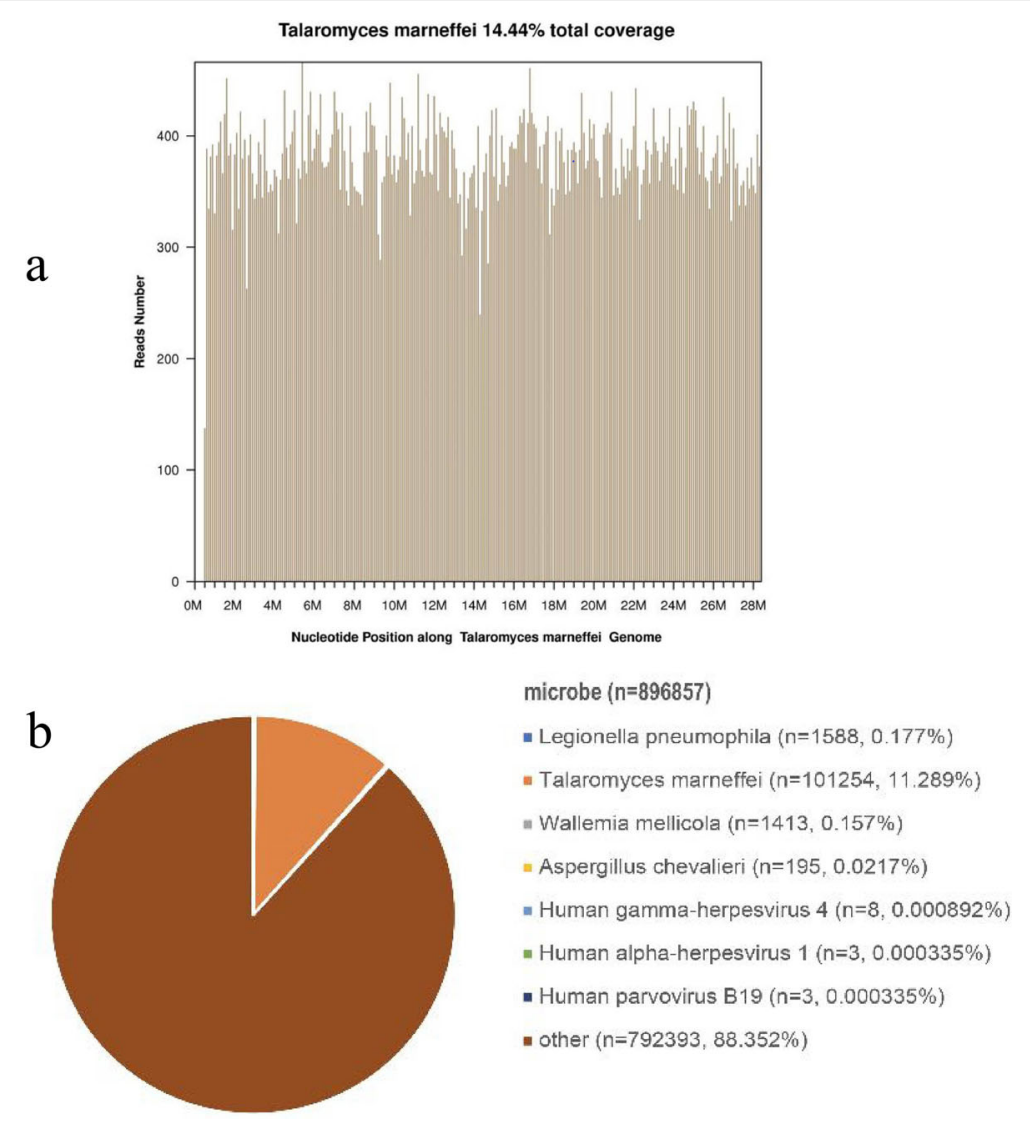

Fig. 3 Pathogen identification from paraffin-embedded tissue samples using the metagenomic next-generation sequencing method. The number of sequencing reads identified that corresponded to Talaromyces marneffei was 101,254 (b) with $14.44 \%$ genome coverage (a). Reads distribution of the total DNA sequence in the sample was without human host

bronchoalveolar lavage fluid [2, 3], bone marrow [2], cerebrospinal fluid [2, 4], and skin lesion [2] specimens.

Talaromyces marneffei is a common opportunistic infection among HIV-infected patients in southeast Asia, southern China, and northeastern India, which are endemic areas for Talaromyces marneffei. Possible epidemiological risk factors are as follows: (1) a history of travel or living in endemic areas and soil exposure, especially during the rainy season, has been suggested to be a critical risk factor; (2) people living with HIV infection, especially $\mathrm{CD}_{4}{ }^{+} \mathrm{T}$-cell counts below 200 cells $/ \mu \mathrm{L}$, contributes to an increased risk of Talaromyces marneffei infection. Common manifestations of disseminated Talaromyces marneffei include fever, anemia, weight loss, skin lesions, respiratory signs, lymphadenopathy, and hepatosplenomegaly. Characteristic cutaneous lesions aids to diagnosis and Talaromyces marneffei infection can be confirmed by positive culture from blood, skin lesion, and bone marrow samples [5]. Inhalation of conidia is the primary route of infection, which then disseminates to the reticuloendothelial system, skin, and gastrointestinal organs. Although gastrointestinal symptoms (e.g., diarrhea) are relatively common with a prevalence of approximately 25\% [6], the prevalence of colonic involvement caused by Talaromyces marneffei infection is only $1.9 \%$ [7]. Including the present case, prominent abdominal involvement from Talaromyces marneffei infection has been reported in a total of 14 patients (Table 1) [4-13]. The main macroscopic pathological changes include multiple gastrointestinal ulcers and mesenteric lymphadenitis. Common distribution of colonic infections include the cecum, ascending colon, appendix, transverse colon, descending colon, or sigmoid colon, small intestine, and duodenum. Common clinical manifestations are fever, diarrhea, abdominal pain, lower gastrointestinal bleeding, and intestinal obstruction. Most patients survive with anti-fungal treatment. Wild bamboo rats exhibit a $100 \%$ prevalence of Talaromyces marneffei infection [14]. It is important to note that the bamboo rat is a common species of rodent bred for meat and wool in southern China. The potential for bamboo rats to transmit pathogens to humans remains unclear because most patients with Talaromyces marneffei infection in Guangdong did not have a history of contact 
Table 1 Summary of clinical characteristics for 14 HIV-infected cases with intestinal Talaromyces marneffei

\begin{tabular}{|c|c|c|c|c|c|c|c|c|}
\hline $\begin{array}{l}\text { Case } \\
\text { No. }\end{array}$ & $\begin{array}{l}\text { Age } \\
\text { (yr)/ } \\
\text { gender }\end{array}$ & $\begin{array}{l}\text { Area and } \\
\text { year of } \\
\text { report }\end{array}$ & $\begin{array}{l}\text { Abdominal } \\
\text { symptoms }\end{array}$ & $\begin{array}{l}\text { Other clinical } \\
\text { presentations }\end{array}$ & $\begin{array}{l}\text { Skin and } \\
\text { mucous } \\
\text { membrane } \\
\text { appearance }\end{array}$ & $\begin{array}{l}\text { Involved organ or } \\
\text { tissue/diagnostic } \\
\text { methods }\end{array}$ & Treatment maintenance & Outcome \\
\hline 1 & $72 / \mathrm{M}$ & $\begin{array}{l}\text { Hong } \\
\text { Kong } \\
\text { China } \\
1992[4]\end{array}$ & Gl bleeding & $\begin{array}{l}\text { anorexia, } \\
\text { dysphagia, } \\
\text { weight loss }\end{array}$ & jejunal ulcer(S) & $\begin{array}{l}\text { small intestine }(B+C) \text {, } \\
\text { mesenteric lymph } \\
\text { node, liver }(A)\end{array}$ & NM & Died \\
\hline 2 & $32 / \mathrm{M}$ & $\begin{array}{l}\text { Hong } \\
\text { Kong } \\
\text { China } \\
1996[5]\end{array}$ & diarrhea & $\begin{array}{l}\text { fever, night } \\
\text { sweats, dry } \\
\text { cough }\end{array}$ & $\begin{array}{l}\text { multiple solitary } \\
\text { ulcers(E) }\end{array}$ & $\begin{array}{l}\text { cecum, transverse and } \\
\text { descending colon(B+ } \\
\text { C) }\end{array}$ & Amphotericin B/Itraconazole & survived \\
\hline 3. 4 & NM & $\begin{array}{l}\text { Thai } 1998 \\
\text { [8] }\end{array}$ & $\begin{array}{l}\text { abdominal } \\
\text { pain }\end{array}$ & fever & NM & $\begin{array}{l}\text { mesenteric lymph node } \\
\text { (B), blood and bone } \\
\text { marrow (C) }\end{array}$ & Amphotericin B & survived \\
\hline 5 & $52 / \mathrm{M}$ & $\begin{array}{l}\text { Taiwan } \\
\text { China } \\
1999 \text { [6] }\end{array}$ & $\begin{array}{l}\text { diarrhea, } \\
\text { abdominal } \\
\text { pain }\end{array}$ & $\begin{array}{l}\text { fever, erupted } \\
\text { papule, anomia, }\end{array}$ & shallow ulcers(E) & $\begin{array}{l}\text { skin, bone marrow }(B+ \\
C) \text {, colons(B) }\end{array}$ & Amphotericin B/Itraconazole & survived \\
\hline 6 & $30 / \mathrm{M}$ & $\begin{array}{l}\text { Taiwan } \\
\text { China } \\
1999 \text { [6] }\end{array}$ & $\begin{array}{l}\text { diarrhea, } \\
\text { abdominal } \\
\text { pain, bloody } \\
\text { stool }\end{array}$ & $\begin{array}{l}\text { dyspepsia, fever, } \\
\text { anomia, weight } \\
\text { loss }\end{array}$ & shallow ulcers(E) & $\begin{array}{l}\text { cecum, ascending and } \\
\text { transverse colons }(B+C)\end{array}$ & Amphotericin B/Itraconazole & survived \\
\hline 7 & $33 / \mathrm{M}$ & $\begin{array}{l}\text { India } \\
2008[7]\end{array}$ & $\begin{array}{l}\text { abdominal } \\
\text { pain }\end{array}$ & $\begin{array}{l}\text { fever, loss of } \\
\text { appetite, weight } \\
\text { loss, vomiting }\end{array}$ & $\begin{array}{l}\text { duodenum } \\
\text { narrowing(E) }\end{array}$ & $\begin{array}{l}\text { duodenum }(B+C) \text {, bone } \\
\text { marrow }(C)\end{array}$ & Amphotericin B/Itraconazole & survived \\
\hline 8 & $39 / M$ & $\begin{array}{l}\text { Hong } \\
\text { Kong } \\
\text { China } \\
2010[9]\end{array}$ & $\begin{array}{l}\text { Abdominal } \\
\text { pain }\end{array}$ & $\begin{array}{l}\text { fever, weight } \\
\text { loss }\end{array}$ & $\begin{array}{l}\text { perioral } \\
\text { umbilicated } \\
\text { lesions }\end{array}$ & $\begin{array}{l}\text { neck and } \\
\text { retroperitoneal } \\
\text { lymph nodes }(H+C) \text {, } \\
\text { blood }(C)\end{array}$ & Amphotericin B/Itraconazole & Survived \\
\hline 9 & $28 / \mathrm{M}$ & $\begin{array}{l}\text { India } \\
2014[10]\end{array}$ & $\begin{array}{l}\text { non-colicky } \\
\text { abdominal } \\
\text { pain }\end{array}$ & $\begin{array}{l}\text { fever, weight } \\
\text { loss }\end{array}$ & $\begin{array}{l}\text { perioral } \\
\text { umbilicated } \\
\text { lesions }\end{array}$ & $\begin{array}{l}\text { neck nodes and } \\
\text { retroperitoneal lymph } \\
\text { nodes }(B+C) \text {, blood }(C)\end{array}$ & Amphotericin B/Itraconazole & survived \\
\hline 10 & $52 / \mathrm{M}$ & $\begin{array}{l}\text { China } \\
2017[11]\end{array}$ & $\begin{array}{l}\text { pain in the } \\
\text { lower left } \\
\text { abdomen }\end{array}$ & $\begin{array}{l}\text { anorexia, weight } \\
\text { loss }\end{array}$ & $\begin{array}{l}\text { multiple solitary } \\
\text { shallow ulcers (E) }\end{array}$ & transverse colon $(\mathrm{B}+\mathrm{H})$ & Itraconazole & survived \\
\hline 11 & $38 / F$ & $\begin{array}{l}\text { India } \\
2020 \text { [12] }\end{array}$ & $\begin{array}{l}\text { colicky } \\
\text { abdominal } \\
\text { pain }\end{array}$ & $\begin{array}{l}\text { loss of appetite, } \\
\text { weight loss }\end{array}$ & $\begin{array}{l}\text { skin lesions, } \\
\text { jejunal ulcers(E) }\end{array}$ & $\begin{array}{l}\text { skin, jejunal ulcers }(B+ \\
\text { C), }\end{array}$ & Amphotericin B/Itraconazole & survived \\
\hline 12 & $37 / M$ & $\begin{array}{l}\text { China } \\
2020 \text { [13] }\end{array}$ & $\begin{array}{l}\text { Abdominal } \\
\text { pain }\end{array}$ & NM & $\begin{array}{l}\text { multiple ulcers } \\
\text { (E) }\end{array}$ & colon (B), blood (C) & Amphotericin B/Itraconazole & Survived \\
\hline 13 & $50 / \mathrm{M}$ & $\begin{array}{l}\text { China } \\
2020 \text { [13] }\end{array}$ & $\begin{array}{l}\text { Abdominal } \\
\text { pain }\end{array}$ & weight loss & $\begin{array}{l}\text { multiple ulcers } \\
\text { (E) }\end{array}$ & colon (B) & $\begin{array}{l}\text { Voriconazole+Amphotericin } \\
\text { B/Itraconazole }\end{array}$ & Survived \\
\hline 14 & $33 / \mathrm{M}$ & $\begin{array}{l}\text { China } \\
{[\mathrm{PR}]}\end{array}$ & $\begin{array}{l}\text { colicky } \\
\text { abdominal } \\
\text { pain, bloody } \\
\text { stool }\end{array}$ & $\begin{array}{l}\text { fever, weight } \\
\text { loss, night } \\
\text { sweats }\end{array}$ & colon ulcers(E) & $\begin{array}{l}\text { Mesenteric lymph } \\
\text { node }(B+N)\end{array}$ & Amphotericin B/Itraconazole & survived \\
\hline
\end{tabular}

ND Not done, NM not mentioned, $P R$ present report

Diagnostic methods to demonstrate P marneffei were autopsy (A), biopsy (B), culture (C), histopathology (H), surgery(S), Endoscope(E), NGS(N)

with bamboo rats [15]. Although the patient's history of bamboo rat consumption is very suggestive, the link between bamboo rat ingestion history in this case and predominantly gastrointestinal presentation requires further study.

This case report has several limitations. The limited size of the omentum majus biopsy tissue was insufficient for tissue culture. Another limitation is a lack of microbial cultivation of bone marrow aspirate. It is unfortunate that we did not perform biopsies of the ulcers identified during the endoscopic examination due to intolerance of the patient and the risk of hemorrhage. Although the lack of an intestinal pathological confirmation from non-specific shallow ulcers infiltrated by lymphocytes and histiocytes distended with yeast [6], intestinal Talaromyces marneffei infection was considered based on the patient's abdominal symptoms of diarrhea, abdominal pain, and bloody stool, which showed total improvement following anti-fungal treatment. 
In conclusion, as a type of culture-independent method, mNGS provides a rapid etiological diagnosis, especially in patients with an uncommon presentation of Talaromyces marneffei infection. FFPE samples of lesions and fresh biopsy specimens may represent suitable specimens for mNGS, which may be convincing for obtaining a targeted diagnosis and treatment.

\section{Abbreviations}

HIV: Human immunodeficiency virus; mNGS: Metagenomic next-generation sequencing; MRI: Magnetic resonance imaging; CT: Computed tomography; H\&E: Hematoxylin and eosin; PAS: Periodic acid-Schiff; GMS: Gomori's methanamine silver nitrate staining; FFPE: Formalin-fixation and paraffinembedded

\section{Acknowledgements}

We thank the patient for agreeing to submit his case. We also thank Xu Wang (Department of endoscopy of the First Affiliated Hospital of China Medical University) for their professional assistance.

\section{Authors' contributions}

YW made the conception and design of the work. YZ helped to collect the data of the case. YW, YZ,YFL wrote the manuscript. All authors carried out final approval of the version to be published.

\section{Funding}

This work was supported by the science and technology foundation of Shenyang (China) of Ying Wen (18-014-4-30) in the First Affiliated Hospital of China Medical University. And Ying Wen made the conception and design of the work.

\section{Availability of data and materials}

Not applicable (no datasets were generated or analyzed during the current report).

\section{Declarations}

Ethics approval and consent to participate

Not applicable.

\section{Consent for publication}

Written informed consent for patient information to be published was provided by the patient.

\section{Competing interests}

The authors declared no potential conflicts of interest with respect to the research, authorship, and/or publication of this article.

\section{Author details}

'Department of Infectious Diseases, The First Affiliated Hospital of China Medical University, No. 155, Nanjing North Street, Heping District, Shenyang 110001, Liaoning Province, China. ${ }^{2} \mathrm{BGI}$ PathoGenesis Pharmaceutical Technology, BGI-Shenzhen, Shenzhen, Guangdong Province, China.

Received: 1 June 2020 Accepted: 9 April 2021

Published online: 21 April 2021

\section{References}

1. Zhu YM, Ai JW, Xu B, Cui P, Cheng Q, Wu H, et al. Rapid and precise diagnosis of disseminated T.marneffei infection assisted by high-throughput sequencing of multifarious specimens in a HIV-negative patient: a case report. BMC Infect Dis. 2018;18(1):379.

2. Pongpech N, Rotjanapan P. Absence of cutaneous involvement in disseminated Talaromyces marneffei infection in an AIDS patient: a case report and literature review. Infect Drug Resist. 2019;12:1493-9. https://doi. org/10.2147/IDR.S207819.

3. Praneenararat S. Fungal infection of the colon. Clin Exp astroenterol. 2014;7: $415-26$.
4. Tsui WMS, Ma KF, Tsang DNC. Disseminated Penicillium marneffei infection in HIV-infected subject. Histopathology. 1992;20(4):287-93. https://doi.org/1 0.1111/j.1365-2559.1992.tb00985.x.

5. Leung R, Sung JY, Chow J, Lai CKW. Unusual cause of fever and diarrhea in a patient with AIDS: Penicillium marneffei infection. Dig Dis Sci. 1996;41(6): 1212-5. https://doi.org/10.1007/BF02088239.

6. Ko Cl, Hung CC, Chen MY, Hsueh PR, Hsiao CH, Wong JM. Endoscopic diagnosis of intestinal penicilliosis marneffei: report of three cases and review of the literature. Gastrointest Endosc. 1999;50(1):111-4. https://doi. org/10.1016/50016-5107(99)70359-7.

7. George IA, Sudarsanam TD, Pulimood AB, Mathews MS. Acute abdomen: an unusual presentation of disseminated Penicillium marneffei infection. Indian J Med Microbiol. 2008;26(2):180-2. https://doi.org/10.4103/0255-0857.40538.

8. Ukarapol N, Sirisanthana V, Wongsawasdi L. Penicillium marneffei mesenteric lymphadenitis in human immunodeficiency virus-infected children. J Med Assoc Thail. 1998;81(8):637-40.

9. Hung HG, Lok KH. Intestinal Penicillium marneffei: an unusual cause of chronic diarrhea in an AIDS patient. J Dig Dis. 2010;11(3):189-91. https://doi. org/10.1111/j.1751-2980.2010.00435.x.

10. Ghalige HS, Sahoo B, Sharma S, Devi KR, Singh Th SC. Acute abdomen due to Penicillium marneffei: an Indicator of HIV infection in Manipur state. J Clin Diagn Res. 2014;8(9):ND05-6.

11. Feng $S$, Wang $X$, Zhang $X$, Yang $H$, Wang Z. Pathological diagnosis of a rare intestinal penicillium marneffei infection in an acquired immunodeficiency syndrome patient: a case report and literature review. Int J Clin Exp Pathol. 2017;10(3):3710-5.

12. Philip Sridhar R, Coelho W, Roopavathana B, Chase S. Opportunistic penicilliosis infection causing intestinal obstruction in people living with HIV complicating antiretroviral therapy. BMJ Case Rep. 2020;13(2):e230121.

13. Pan M, Huang J, Qiu Y, Zeng W, Li Z, Tang S, Wei X, Zhang J. Assessment of Talaromyces Marneffei Infection of the Intestine in Three Patients and a Systematic Review of Case Reports. Open Forum Infect Dis. 2020;7(6): ofaa128.

14. Cao C, Liang L, Wang W, Luo H, Huang S, Liu D, et al. Common reservoirs for Penicillium marneffei infection in humans and rodents. China Emerg Infect Dis. 2011;17(2):209-14. https://doi.org/10.3201/eid1702.100718.

15. Li X, Yang Y, Zhang X, Zhou X, Lu S, Ma L, et al. Isolation of Penicillium marneffei from soil and wild rodents in Guangdong. SE China Mycopathologia. 2011;172(6):447-51. https://doi.org/10.1007/s11046-0119443-5.

\section{Publisher's Note}

Springer Nature remains neutral with regard to jurisdictional claims in published maps and institutional affiliations.

\section{Ready to submit your research? Choose BMC and benefit from:}

- fast, convenient online submission

- thorough peer review by experienced researchers in your field

- rapid publication on acceptance

- support for research data, including large and complex data types

- gold Open Access which fosters wider collaboration and increased citations

- maximum visibility for your research: over $100 \mathrm{M}$ website views per year

At BMC, research is always in progress.

Learn more biomedcentral.com/submissions 